\title{
Benzine Extract from Sonchus asper-A Rich Source of Pentacyclic Triterpenoids
}

\author{
Mukat BEHARI*, Rajiv GuPTA*, Toshihiro ITOH**, \\ and Taro MATSUMOTO** \\ * Chemical Laboratories, Shri Varshney College \\ (Aligarh-202001, India) \\ ** College of Science and Technology, Nihon University \\ (1-8, Kanda Surugadai, Chiyoda-ku, Tokyo)
}

\begin{abstract}
Pentacyclic triterpene alcohols (9.8\%), their acetates (16.1\%), and their long chain fatty acid esters (4.6\%) represent $30.5 \%$ of the benzine extract from the herb of Sonchus asper Vill. (Compositae). The composition of triterpene alcohols was: $\alpha$-amyrin (4\%), $\beta$-amyrin (8\%), germa $=$ nicol (6\%), $\psi$-taraxasterol (17\%), taraxasterol (36\%), lupeol (28\%), and other unidentified components $(1 \%)$; and that of triterpene acetates was: $\alpha$-amyrin acetate $(3 \%), \beta$-amyrin acetate $(8 \%)$, germanicol acetate (5\%), $\psi$-taraxasterol acetate (19\%), taraxasterol acetate (21\%), and lupeol acetate (44\%). Triterpene alcohol moiety of the long chain fatty acid esters was $\gamma$-taraxasterol only. The results indicate that the benzine extract from $S$. asper Vill. can be used as a good source of pentacyclic triterpenoids.
\end{abstract}

\section{Introduction}

Sonchus asper Vill. is a annual herb of the family Compositae, commonly known as "Jan= gali Gobhi". It is pounded and applied to wounds and boils ${ }^{12}$. Considering its medicinal use and the fact that no work has so far been carried out on the chemical constituents, the present study was undertaken in an attempt to elucidate the compositional patterns of the benzine extract of this herb. This paper is concerned with the triterpenoid constituents.

\section{Experimental}

\subsection{Materials}

Sonchus asper, collected on the campus of Shri Varshney College, Aligarh (India), was air-dried, ground, and extracted in a Soxhlet extractor with benzine (bp $60 \sim 80^{\circ} \mathrm{C}$ ) for $18 \mathrm{~h}$. A yellow viscous oil (2.1\%) was obtained after removal of solvent under reduced pressure.

The origin of the following authentic triter= pene alcohols was described in the previous paper $^{2)}: \alpha$-amyrin $(5 \alpha$-urs-12-en- $3 \beta$-ol $), \quad \beta$ amyrin ( $5 \alpha$-olean-12-en-3 $\beta$-ol), germanicol ( 5 $\alpha$-olean-18-en-3 $\beta$-ol), taraxasterol ( $5 \alpha$-taraxast $-20[29]-$ en- $3 \beta-\mathrm{ol})$, and $\gamma$-taraxasterol $(5 \alpha-$ taraxast-20-en-3 $\beta$-ol). Lupeol ( $5 \alpha$-lup-20[29] -en-3 $\beta$-ol) was generously supplied from Dr. M. P. Khare as a gift.

\subsection{General}

Crystallizations were performed in acetonemethanol. Melting points determined on a heat block were uncorrected. Hydrolysis of fatty acid esters was performed by refluxing with alcoholic $1 \mathrm{~N}$ potassium hydroxide for $1 \mathrm{~h}$, and acetylation of triterpene alcohols was accoms plished with acetic anhydride and pyridine at room temp. over night.

TLC was carried out on Silica Gel G plates with carbon tetrachloride-ethyl acetate (95:5, $\mathrm{vol} / \mathrm{vol}$ ) as the developing solvent. The fols lowing $R_{f}$-values are illustrative: hydrocarbons 1.0 , esters of higher fatty acids 0.9 , triterpene 
acetates 0.82 , triterpene alcohols 0.51 , and sterols 0.33 . Preparative argentation TLC on plates coated with $0.5 \mathrm{~mm}$ layers of Silica Gel $G$ impregnated with $20 \%$ silver nitrate was developed 5 times with methylene chloridecarbon tetrachloride $(1: 5, \mathrm{vol} / \mathrm{vol})$. GLC was performed by a Shimadzu GC- $4 \mathrm{CM}$ instrument equipped with a flame ionization detector on Poly I-110 (column $270^{\circ} \mathrm{C}$, injection $285^{\circ} \mathrm{C}$, car= rier gas $80 \mathrm{ml} / \mathrm{min}$, split ratio $50: 1$, scavenge gas $80 \mathrm{ml} / \mathrm{min}$, retention time of cholesterol acetate ca. $20 \mathrm{~min}$ ) and on $\mathrm{OV}-17$ (column $260^{\circ} \mathrm{C}$, injection $280^{\circ} \mathrm{C}$, carrier gas $60 \mathrm{ml} / \mathrm{min}$, split ratio $50: 1$, scavenge gas $80 \mathrm{ml} / \mathrm{min}$, re= tention time of cholesterol acetate ca. $18 \mathrm{~min}$ ) in the form of SCOT glass capillary columns ( $30 \mathrm{~m} \times 0.3 \mathrm{~mm}$ i. d., Wako Pure Chemical In dustries Ltd., Osaka). The relative retention time (RRT) was given relative to cholesterol acetate. Since the component peaks with long retention time appeared with "leading" on OV17, the retention time of GLC peaks was de= fined here on both Poly $\mathrm{I}-110$ and OV-17 columns at the starting point of the elution peak appearance instead of at the usual top edge of the peak. Quantitative evaluation of each triterpene component was carried out bac sed on the argentation TLC data and on the GLC data on Poly I-110.

IR spectra were recorded on a Perkin-Elmer spectrometer using $\mathrm{KBr}$ discs. Nuclear mas gnetic resonance (NMR) spectra were recorded either on a Varian spectrometer A-60 D or on a JNM-FX 100 (Japan Electron Optics Labo= ratory Co., Tokyo), in deuteriochloroform using tetramethylsilane as the internal standard. Chemical shifts are expressed in $\delta$-scales $(\mathrm{ppm})$. Mass spectra $(70 \mathrm{eV})$ were taken with a Shimadzu LKB-9000 gas chromatograph-mass spectrometer $(2 \mathrm{~m} \times 3 \mathrm{~mm}$ i. d. glass column packed with a $2 \%$ OV-17 on Gas Chrom-Q).

\section{Results}

The benzine extract was chromatographed by column chromatography on activated alumina. The column was developed with hexane and benzine-benzene. The eluate was monitored periodically by the TLC and separated into the following five fractions: pentacyclic triterpene alcohols $(9.8 \%$ on the extract basis), their acetates (16.1\%) and their higher fatty acid esters (4.6\%), and hydrocar= bons and sterols.

\subsection{Higher Fatty Acid Esters of Tris terpene Alcohols}

The alcohol obtained after hydrolysis of the fatty acid ester fraction was acetylated. The acetate was separated on argentation TLC plate into three zones, aliphatic alcohol acetates (fraction 1), sterol acetates (fraction 2), and $\psi$-taraxasterol acetate (fraction 3 ); the frac $=$ tions were numbered in the order of polarity, beginning with the least polarity. Identification of $\psi$-taraxasterol was performed by co-TLC and GLC with an authentic specimen as the acetate.

\subsection{Triterpene Acetates}

The fraction of triterpene acetates exhibited prominent IR bands at $1730,1248 \mathrm{~cm}^{-1}$ (aceta= te), $1640 \mathrm{~cm}^{-1}(\mathrm{C}=\mathrm{C}), 1366,1388 \mathrm{~cm}^{-1}$ (geminal dimethyl group). NMR spectrum of the acetate gave the signals at $\delta 0.75,0.81,0.86,0.96$, $1.05,1.27,1.41$ and 1.46 ; singlet at $\delta 2.03$ $\left(-\mathrm{OCOCH}_{3}\right)$ and multiplet at $\delta$ 4.29 4.6 $(>\mathrm{CHOAc}), 4.59 \sim 4.69\left(>\mathrm{C}=\mathrm{CH}_{2}\right)$, and 4.76 $\left.\sim 4.92(>\mathrm{C}=\mathrm{CH}-)^{3}\right)$. This fraction was frac $=$ tionated by preparative argentation TLC to give eight principal zones, $\mathrm{i}$ to viii, in the order of decreasing $R_{f}$-values.

(i) $\boldsymbol{\alpha}$-Amyrin acetate: The compound separated from the first zone was crystallized as fine plates $(3 \%)$, having $\mathrm{mp} 221 \sim 223^{\circ} \mathrm{C}$ (lit. ${ }^{4)} \mathrm{mp} 226^{\circ} \mathrm{C}$ ), $R_{f}$-value 0.61 , RRT 1.98 (Poly I-110), 1.84 (OV-17). The mass specs trum of this acetate showed $\mathrm{M}^{+}$at $m / e 468$ (18\%) and other ions at $m / e 453$ (4.4), 408 (3.3), 249 (4.2), 218 (100), 203 (16), 189 (12). The strong peak at $m / e \quad 218$ is characs teristic for the $\alpha$ - and $\beta$-amyrin series. The RRT and the basic fragmentation pattern ${ }^{5}$ of this compound confirmed it to be $\alpha$-amyrin acetate.

(ii) $\boldsymbol{\beta}$-Amyrin acetate: The second zone gave fine prisms after crystallization (8\%), having $\mathrm{mp} 241 \sim 244^{\circ} \mathrm{C}$ (1it. ${ }^{4)} \mathrm{mp} 241^{\circ} \mathrm{C}$ ), $R_{f^{-}}$ value 0.57 , RRT 1.68 (Poly I-110), 1.64 (OV17). The mass spectrum of the acetate showed $\mathrm{M}^{+}$at $m / e 468(15 \%)$ and other ions at $m / e$ 453 (5.0), $408(2.2), 249$ (2.4), 218 (100), 203 (24), 189 (8.0). This compound was 
confirmed as $\beta$-amyrin acetate on the basis of mass fragmentation $^{5}$ (strong peak at $m / e$ 218) and RRT data.

(iii): This zone consisted of a mixture of several unidentified compounds $(<0.5 \%)$.

(iv); Germanicol acetate: The compound separated from the zone iv was crystallized as fine plates $(5 \%)$, having $\mathrm{mp} 279 \sim 281^{\circ} \mathrm{C}$ (lit. ${ }^{6)}$ $\mathrm{mp} 281 \sim 282^{\circ} \mathrm{C}$ ), $R_{f}$-value 0.37 and RRT 1.68 (Poly I-110), 1.64 (OV-17). The mass spec= trum of the triterpene acetate showed $\mathrm{M}^{+}$at $m / e 468(17.5 \%)$ and other ions at $m / e 453$ $(18.0), 408(8.2), 393(9.0), 218(23.5), 204$ (100), 189 (95.0), $177(70.0)$, which is iden= tical with that of germanicol acetate reported in the literature and the spectrum was fully agreeable to that compound $^{6) \sim 8}$. The NMR spectrum was also in accordance with that of germanicol acetate reported in the literature ${ }^{7,9)}$ : $3 \beta$-Ac $\delta 2.05, \mathrm{C}-3$ (CH-O) 4.47, C-23, C-24 $\left(2 \times \mathrm{CH}_{3}\right) 0.84, \mathrm{C}-25\left(\mathrm{CH}_{3}\right) 0.90, \mathrm{C}-26\left(\mathrm{CH}_{3}\right)$ 1.07, C-27 $\left(\mathrm{CH}_{3}\right)$ 0.73, $\mathrm{C}-28\left(\mathrm{CH}_{3}\right) 1.01, \mathrm{C}-29$ $\left(\mathrm{CH}_{3}\right)$ 0.94, C-30 $\left(\mathrm{CH}_{3}\right)$ 0.94, $\mathrm{C}-19$ (olefin) 4.85 . Assignment of each signal in the spectrum was carried out by the experiment with a lanthanide shift reagent, tris (dipivaloylmethanato) euro= pium, in a similar manner as described by Shingu et al. ${ }^{10)}$ Thus on the basis of mass fragmentation and NMR spectrum this coms pound was confirmed as germanicol acetate. The chromatographic and spectral data of au= thentic germanicol acetate supported the iden= tification.

(v) $\Psi$-Taraxasterol acetate: The com $=$ pound separated from the zone $\mathrm{v}$ was crystallized as fine needles (19\%), having $\mathrm{mp} 236 \sim 238^{\circ} \mathrm{C}$ (lit. $\left.{ }^{11)} \mathrm{mp} 235^{\circ} \mathrm{C}\right), R_{f}$-value 0.33 and RRT 2.66 (Poly I-110), 2.41 (OV-17). The mass spectrum of the acetate showed $\mathrm{M}^{+}$at $m / e 468$ (12.9\%) and other ions at $\mathrm{m} / \mathrm{e} 453$ (11.8), 408 (9.6), 218 (67.8), 203 (35.8), 189 (100). This compound was confirmed as $\psi$-taraxasterol acetate on the basis of mass fragmentation ${ }^{5}$ and RRT data.

(vi) Taraxasterol acetate: It was crys= tallized as fine plates (21\%), having mp 249 $251^{\circ} \mathrm{C}$ (lit. ${ }^{11)} \mathrm{mp} 251 \sim 2^{\circ} \mathrm{C}$ ), $R_{f}$-value 0.29 and RRT 2.71 (Poly I-110), 2.51 (OV-17). The mass spectrum of the acetate gave $\mathrm{M}^{+}$at $m / e$ $468(16.4 \%)$ and other peaks at $m / e 453(7.3)$,
408 (13.3), 393 (8.7), 218 (4.5), 203 (31.7), 189 (100). The RRT and the fragmentation pattern of the triterpene acetate were identical with those of authentic taraxasterol acetate ${ }^{12)}$. Hence this triterpene acetate was recognized as taraxasterol acetate.

(vii): This zone $\left(<0.5 \% 0^{\prime}\right)$ was a mixture of taraxasterol acetate and lupeol acetate.

(viii) Lupeol acetate: This compound was crystallized as fine needles (44\%), having $\mathrm{mp}$ $219 \sim 20^{\circ} \mathrm{C}$ (lit. ${ }^{4)} \mathrm{mp} 220^{\circ} \mathrm{C}$ ), $R_{f}$-value 0.10 and RRT 1.91 (Poly I-110), 1.92 (OV-17). Mass spectrum of the acetate gave $\mathrm{M}^{+}$at $m / \mathrm{c} 468$ $(11.4 \%)$ with other principal ions at $\mathrm{m} / \mathrm{e} 453$ (5.8), 408 (15.8), $393(8.2), 218(15.4), 203$ (19.8) and 189 (100). The RRT and basic fragmentation patterns agreed with those of authentic lupeol acetates). Consequentiy the triterpene acetate was recognized as lupeol acetate.

\subsection{Triterpene Alcohols}

The triterpene alcohol fraction after acetyla= tion was separated into two fractions by column chromatography on silica gel impregnated with $20 \%$ silver nitrate. The 2 nd major fraction was found to be a mixture of six triterpene alcohols, identified as the acetates on the basis of co-TLC and GLC as $\alpha$-amyrin $\left(4,0^{\circ}\right), \beta-$ amyrin $(8, \%)$, germanicol $(6 \%)$, $;$-taraxasterol $(17 \%)$, taraxasterol $\left(36,0^{\prime}\right)$ and lupeol $\left(28,0^{\circ}\right)$, accompanied with other minor unidentified components $\left(1 \%{ }^{\circ}\right)$.

\section{Discussion}

Pentacyclic triterpenoids have been found as the minor components in many seed oils ${ }^{32,133}$ and often represent the greater part of the unsaponifiable portion of these oils. They are usually associated with hydrocarbons, sterols and other triterpene alcohols, especially with cycloartenol and 24-methylenecycloartanol. A few oils of plant origin, however, have been reported to contain a large amount of penta $=$ cyclic triterpenoids: the ethanol extract con= taining as high as about $80 \%$ of pentacyclic triterpenoids from the latex exuded from the bark of Achras sapsta ${ }^{14}$, the petroleum ether extract containing about $40 \%$ of pentacyclic triterpenoids from the fruit (seed and pericarp) of two Jurinea species ${ }^{15}$, and the petroleum 
ether extract containing about $50 \%$ of penta $=$ cyclic triterpenoids from the seed and pericarp of Carduus nigrescens ${ }^{5}$.

Our finding indicates that pentacyclic triter= penoids occur in the extract of $S$. asper as the acetate, esters of higher fatty acids as well as in the form of triterpene alcohols, along with hydrocarbons, esters of aliphatic alcohols, and sterols. The total yield of all the triterpenoids has been found to be $30.5 \%$ of the benzine extract of the plant and indicates that the extract of $S$. asper can be used as a good source of pentacyclic triterpenoids.

\section{Acknowledgments}

The authors are grateful to Dr. S. C. Gupta and Dr. W. Rahman (Aligarh) for facilities. Thanks are also due to Dr. S. Singh (Lucknow) for IR and NMR spectra, and to U.G.C., Delhi for J.R.F. to R. Gupta. Prof. Y. Toyama con= tributed valuable comments and advices.

(Received May 15, 1979)

\section{References}

1) R.N. Chopra, S.L. Nayar, and I.C. Chopra, "Glossary of Indian Medicinal Plants", C.S.I. R., New Delhi (1956) p. 230.

2) T. Itoh, T. Tamura, and T. Matsumoto, AOCS Meeting Paper No. 187, San Francisco, April/ May (1979)

3) T. Itoh, T. Tamura, and T. Matsumoto, Lipids, 9, 173 (1974).

4) Elsevier's Encyclopaedia of Organic Chemistry, Vol. 14, Amsterdam (1940).

5) R.V. Madrigal, R.D. Plattner, and C.R. Smith, Jr., Lipids, 10, 208 (1975).

6) Y.L. Chow and H.H. Quon, Phytochemistry, 9, 1151 (1970).

7) D. Abramson, L.J. Goad, and T.W. Goodwin, Phytochemistry, 12, 2211 (1973).

8) H. Budzikiewicz, J.M. Wilson, and C. Djerassi,
J. Am. Chem. Soc., 85, 3688 (1963).

9) A.G. González, J.L. Breton, and B.M. Fraga, Rev. Latinoam. Quim., 2, 167 (1972).

10) T. Shingu, T. Yokoi, M. Niwa, and T. Kiku= chi, Chem. Pharm. Bull., 21, 2252 (1973).

11) Dictionary of Organic Compounds (I.M. Heile bron and H.M. Bunbury, Eds.) Vol. II, 2 nd Ed., Oxford Univ. Press (1953).

12) N.A. Chaudhary and D. Ghosh, Phytochemis stry, 9, 1885 (1970).

13) T. Itoh, T. Tamura, and T. Matsumoto, $J$. Am. Oil Chem. Soc., 50, 300 (1973).

14) E. Azoeitia, A. Bowers, P. Crabbé, O. Man= cera, J.S. Matthews, J. Reynoso, and J. Salazar, Can. J. Chem., 39, 2321 (1961).

15) K.L. Mikolajczak and C.R. Smith, Jr., Lipids, 2, 127 (1967).

五環性トリテルペノイド成分に富む おにのげしのベンジン抽出油

Mukat Behari*, Rajiv Gupta*, 伊藤俊博 ${ }^{* *}$, 松本太郎**

* Chemical Laboratories, Shri Varshney College ** 日本大学理工学部

おにのげし(きく科) のベンジン抽出物は五環性トリ テルペノイド成分に富み, 遊離の五環性トリテルペンア ルコール (9.8\%)，それらのアセタート $(16.1 \%)$ 及び 長鎖脂肪酸エステル (4.6\%) で，その和は全抽出物の $30.5 \%$ をも占めていた。遊離トリテルペンアルコール 混合物の組成は $\alpha$-アミリン (4\%), $\beta$-アミリン $(8 \%)$, ゲルマニコール (6\%), $\psi$ ータラクサステロール $(17 \%)$, タラクサステロール (36\%)，ルペオール (28\%) 及び 末同定成分 $(1 \%)$ であり，トリテルペンアセタート混合 物の組成は $\alpha$-アミリンアセタート $(3 \%), \quad \beta$-アミリン アセタート (8\%)，ゲルマニコールアセタート (5\%), ঋータラクサステロールアセタート (19\%)，タラクサス テロールアセタート (21\%) 及びルペオールアセタート (44\%）であった。一方，長鎖脂肪酸 エステルより得ら れたトリテルペン成分としては $\psi$ タラクサステロール のみが検出された。以上の結果は, おにのげし油が五環 性トリテルペノイドを得る優れた原料であることを示す ものである。 